\title{
Delayed effect of heat stress on steroid production in medium-sized and preovulatory bovine follicles
}

\author{
Z. Roth¹, R. Meidan ${ }^{1}$, A. Shaham-Albalancy ${ }^{1}$, \\ R. Braw-Tal ${ }^{2}$ and D. Wolfenson ${ }^{1 *}$ \\ ${ }^{1}$ Department of Animal Science, Faculty of Agricultural, Food and Environmental \\ Quality Sciences, The Hebrew University of Jerusalem, Rehovot 76100, Israel; and \\ ${ }^{2}$ Institute of Animal Science, Agricultural Research Organization, The Volcani Center \\ Bet Dagan 50250, Israel
}

During the autumn, the conception rate of dairy cattle in warm countries is low although ambient temperatures have decreased and cows are no longer exposed to summer thermal stress, indicating that there may be a delayed effect of heat stress on cattle fertility. Two experiments were conducted to examine possible delayed effects of heat stress on follicular characteristics and steroid production at two distinct stages of follicular growth: medium-sized and preovulatory follicles, 20 and 26 days after heat exposure, respectively. Lactating cows were subjected to heat stress for $12 \mathrm{~h}$ a day in an environmental chamber, during days 2-6 of a synchronized oestrous cycle. In Expt 1, ovaries were collected on day 3 of the subsequent cycle, before selection of the dominant follicle, and medium-sized follicles were classified as atretic or healthy. In Expt 2, on day 7 of the subsequent cycle, $\mathbf{P G F}_{2 \alpha}$ was administered and preovulatory follicles were collected $40 \mathrm{~h}$ later. In both experiments, follicular fluid was aspirated, granulosa and thecal cells were incubated, and steroid production was determined. In healthy medium-sized follicles (Expt 1), oestradiol production by granulosa cells and androstenedione production by thecal cells were lower $(P<0.05)$ and the concentration of progesterone in the follicular fluid was higher in cows that had been previously heat-stressed than in control cows $(P<0.05)$. In preovulatory follicles (Expt 2), the viability of granulosa cells was lower $(P<0.05)$ and the concentration of androstenedione in the follicular fluid and its production by thecal cells were lower $(P<0.05)$ in cows that had been previously heatstressed than in control cows. In both experiments, the oestradiol concentrations in the follicular fluids were not altered by heat stress. These results demonstrate a delayed effect of heat stress on steroid production and follicular characteristics in both medium-sized and preovulatory follicles; this effect could be related to the low fertility of cattle in the autumn.

\section{Introduction}

The low summer fertility of about $60 \%$ of the world dairy cattle population is associated with high ambient temperatures. However, during the autumn, when air temperatures have decreased and cows are no longer exposed to thermal stress, conception rates remain lower than in the winter (Hansen, 1997). This observation may be explained by the facts that ovarian follicles are susceptible to heat stress (Badinga et al., 1993; Wolfenson et al., 1995) and that it takes about 40-50 days for small antral follicles to develop into large dominant follicles (Lussier et al., 1987). Thus, exposure to summer heat stress during the early stages of follicular development may impair later follicular function and decrease fertility in the autumn. Clear delayed effects of summer heat stress on follicular function have been

*Correspondence

Email:wolf@agri.huji.ac.il observed: (i) a markedly low quality of oocytes collected after summer heat stress was associated with low developmental capability of embryos in vitro during the autumn (Roth et al., 1999); and (ii) alterations in the pattern of growth and development of medium-sized follicles associated with a marked increase in plasma FSH concentration were found during the first follicular wave of the oestrous cycle, subsequent to heat exposure (Roth et al., 2000a). A seasonal study has shown that oestradiol concentration in the follicular fluid and androstenedione production by thecal cells were both lower in dominant follicles collected in autumn than in those collected in winter (Wolfenson et al., 1997). However, seasonal studies provided only limited information regarding a delayed effect of heat stress on follicular steroidogenesis owing to their multifactorial nature and the fact that proper contemporary control animals could not be used in such studies.

The aim of the present study was to examine a possible delayed effect of acute heat stress on follicular characteristics. Steroid production by granulosa and thecal cells was 
studied at two distinct stages of follicular growth: in medium-sized follicles before selection of the dominant follicle and in preovulatory follicles 3-4 weeks after heat exposure ended.

\section{Materials and Methods}

Two experiments were conducted in the winter. Experimental design, tissue collection and cell incubation were identical in both experiments. Delayed effects of 5 days of heat exposure on steroid production were examined in medium-sized (Expt 1) and preovulatory (Expt 2) follicles.

\section{Animals}

Mature, cyclic Holstein dairy cows were selected for the study. All experimental cows were housed in identical chambers in the same shelter under the same husbandry conditions from 1 week before cows were assigned to the experimental groups to eliminate a possible confinement effect. The cows were in late lactation, yielding an average of $25 \mathrm{~kg}$ milk per day. The cows were fed a complete mixed ration containing $16.5 \%(\mathrm{w} / \mathrm{v})$ crude protein and 1.65 Mcal per $\mathrm{kg}$ dry matter. This study has been reviewed and approved by the appropriate institutional animal care and use committee.

\section{Experimental protocol}

For synchronization of oestrus, an intravaginal progesterone insert (CIDR; Eazi Breed, Hamilton) was inserted for 9 days and $500 \mu$ g cloprostenol, a PGF 20 analogue (Estrumate; Coopers, Berkhamsted), was injected i.m. 7 days after insertion of the intravaginal progesterone implant. Cows were checked for signs of oestrus three times a day for $30 \mathrm{~min}$ each time. Cows expressing oestrous behaviour within $48 \mathrm{~h}$ after removal of the CIDR were included in the experiment. On day 2 of the oestrous cycle, after confirmation of ovulation by ultrasonography, cows were assigned randomly to either control or heat-stressed groups. All cows were kept in the same shelter and were milked in their housing environment. Control cows were housed in the chambers under normothermic conditions and heat-stressed cows were kept in similar chambers in which air temperature and relative humidity were increased to $36^{\circ} \mathrm{C}$ and $60 \%$, respectively. Heat-stressed cows were exposed to thermal stress for $12 \mathrm{~h}$ a day, between 07:00 $\mathrm{h}$ and 19:00 h, during days 2-6 of the cycle. This early stage of the cycle was chosen because the first follicular wave is considered to be highly predictable in terms of follicular dynamics. Although a 5 day duration of thermal stress was sufficient to induce a significant immediate effect on follicular steroidogenesis, a possible delayed effect was not determined (Wolfenson et al., 1997). Accordingly, it was decided to examine the delayed responses to such a short heat stress in the time frame of the subsequent cycle, within 4 weeks after the end of heat exposure. At the end of heat exposure, on day 7 of the oestrous cycle, control and heat- stressed cows were grouped together and housed under normothermic conditions. In both experiments, on day 18 of the treated cycle, $\mathrm{PGF}_{2 \alpha}$ analogue $(500 \mu \mathrm{g}$ was injected and cows showed signs of oestrus, on average, on day 21 of the cycle. This synchronization procedure enabled the interval between the end of heat exposure and the days in the subsequent cycle on which ovaries were collected to be set at a similar duration for all cows. Blood samples were collected once a day during days 2-19 in the treated cycle in both experiments, and during days 1-3 and days 1-7 of the subsequent cycle in Expt 1 and Expt 2, respectively. Blood samples were centrifuged at $2000 \mathrm{~g}$ for $20 \mathrm{~min}$ and plasma was stored at $-20^{\circ} \mathrm{C}$ for determination of oestradiol and progesterone concentrations.

In Expt 1, ovaries from control $(n=6)$ and heat-stressed $(n=5)$ cows were collected on day 3 of the subsequent cycle, 20 days after heat exposure was ended. The day of ovary collection was selected to obtain the maximal number of medium-sized follicles of the first follicular wave before the suppressive influence of the dominant follicle (Ginther et al., 1989; Fortune et al., 1991). Follicular development was examined at 2 day intervals, from day 15 of the treated cycle to day 3 of the subsequent cycle, using an ultrasound instrument (model SSD-210DXII; Aloka, Tokyo) equipped with a $7.5 \mathrm{MHz}$ transducer. Positions and sizes of follicles and corpora lutea in the ovaries were traced at each scanning and the exact location of the follicles was recorded. This procedure enabled individual follicles to be identified accurately during dissection of the ovaries and selection of medium-sized follicles that had grown during the first follicular wave of the subsequent cycle and not those from the previous (treated) cycle.

In Expt 2, heat stress was applied on days 2-6 of the cycle, as described for Expt 1. On day 7 of the subsequent cycle, PGF $_{2 \alpha}$ analogue $(500 \mu \mathrm{g})$ was injected to induce regression of the corpus luteum and development of the first wave preovulatory follicle and, after a further $40 \mathrm{~h}$, ovaries were collected from both heat-stressed $(n=4)$ and control $(n=5)$ cows. Comparison of the morphology of the ovaries with the ultrasonography records obtained on days 2, 4, 6 and 8 of the subsequent cycle enabled easy identification of the preovulatory follicles.

\section{Tissue collection and cell incubation}

Ovaries from experimental cows were collected at the abattoir after the cows were killed. During dissection of the ovaries, the follicular diameter was measured with callipers and follicular fluid from each follicle was aspirated and stored separately at $-20^{\circ} \mathrm{C}$ for determination of steroid concentrations. The granulosa and thecal cells were isolated from medium-sized follicles $(6-9 \mathrm{~mm}$ in diameter; Expt 1) or preovulatory follicles (Expt 2), dispersed enzymatically and cultured separately. The viability of granulosa and thecal cells was determined with $0.1 \%(\mathrm{w} / \mathrm{v})$ trypan blue as described previously (Meidan et al., 1990; Wolfenson et al., 1999, Shores et al., 2000). Long-term 
experience in our laboratory has shown that low viability of granulosa cells, as assessed by trypan blue, is associated closely with oestradiol:progesterone concentration ratios $<1$ in the follicular fluid. For example, Shaham-Albalancy et al. (2000) found that granulosa cell viability and oestradiol and progesterone concentrations in the follicular fluid of healthy and atretic follicles were $66 \%, 31 \mathrm{ng} \mathrm{ml}^{-1}$ and $16 \mathrm{ng} \mathrm{ml}^{-1}$ versus $35 \%, 1 \mathrm{ng} \mathrm{ml}^{-1}$ and $77 \mathrm{ng} \mathrm{ml}^{-1}$, respectively. Accordingly, in Expt 1, medium-sized follicles that expressed low viability of granulosa cells were classified as atretic follicles and were not subjected to further examination; the cell viability of these follicles was $21.3 \pm 5.4$ and $18.6 \pm 2.8 \%$ in control and heat-stressed cows, respectively. Follicles that had $>50 \%$ viability of granulosa cells were classified as healthy follicles and were subjected to further examination. The status of the healthy medium-sized follicles was verified later by the observation of $a>1$ ratio of oestradiol:progesterone concentrations in the follicular fluid (Ireland and Roche, 1983). Cells $\left(10^{5}\right.$ viable cells per well) from individual healthy follicles were incubated in a final volume of $0.5 \mathrm{ml}$ in a 24-well plate (Nunc, Kampstrup) in Dulbecco's minimum essential medium with Ham's F-12 1:1 (v/v) nutrient mixture (Gibco, BRL Life Technologies, Gaithersburg, MD), containing 1\% fetal calf serum (Biological Industries, Beit Ha'emek). Cells were incubated for $6 \mathrm{~h}$ to determine steroid production before spontaneous luteinization; a previous study in our laboratory had indicated that granulosa cells maintained aromatase activity after $6 \mathrm{~h}$ of incubation (R. Meidan and D. Wolfenson, unpublished). Cells were incubated at $38^{\circ} \mathrm{C}$ under $5 \% \mathrm{CO}_{2}$. Granulosa cells were incubated in medium only or with the addition of testosterone (300 $\mathrm{ng} \mathrm{m}^{-1}$; Sigma, St Louis, MO). Thecal cells that had been isolated from preovulatory follicles were incubated in medium only or with the addition of forskolin (10 $\mathrm{mmol} \mathrm{I}^{-1}$; Sigma) or LH (50 ng ml-1; USDA bLH-B-5, provided through the USDA Animal Hormone Program, Beltsville, MD). Thecal cells that had been isolated from medium-sized follicles were incubated in medium only or with forskolin (but not with $\mathrm{LH}$, for technical reasons). Three replicate wells were used for each treatment. At the end of incubation, media were collected from all wells and stored separately at $-20^{\circ} \mathrm{C}$ for determination of steroid concentrations.

\section{Hormone analyses}

Plasma samples were extracted with diethyl ether as described by Badinga et al. (1992). Concentrations of oestradiol, androstenedione and progesterone in follicular fluid and medium, as well as the concentrations of progesterone in extracted plasma, were determined by radioimmunoassays that had been validated previously in our laboratory (Meidan et al., 1990; Wolfenson et al., 1997, 1999) with specific antibodies (Sigma). The sensitivities of the assays were 1.92, 3.9 and 3.9 pg per tube for oestradiol, androstenedione and progesterone, respectively. Intra- and interassay coefficients of variation were $9.9,13.3$ and $4.6 \%$, and 13.2, 13.9 and $8.6 \%$ for oestradiol, androstenedione and progesterone, respectively. Oestradiol concentrations in extracted plasma samples were determined by means of a radioimmunoassay described by Badinga et al. (1992) that had been validated in our laboratory (Shaham-Albalancy et al., 1997; Roth et al., 2000a). Assay sensitivity was 0.5 pg $\mathrm{ml}^{-1}$, and the intra- and interassay coefficients of variation were 3 and $5 \%$, respectively.

\section{Statistical analysis}

The General Linear Models procedure of the Statistical Analysis System was used (SAS, 1987). Data relating to follicular characteristics and hormonal concentrations in the follicular fluid and media were analysed by one-way ANOVA, separately for each type of follicle and cell. The data of steroid hormone concentrations in the media of the three replicate wells for each treatment were averaged, and were analysed separately for basal and stimulated oestradiol and androstenedione production. Concentrations of steroid hormones in the media are expressed as ng per $10^{5}$ viable cells. The statistical model for concentration of hormones in plasma included effects of treatment (control versus heat stress groups), cow (within treatment), day of oestrous cycle, and treatment by day interaction. Data are presented as mean $\pm \mathrm{SE}$.

\section{Results}

Body temperatures of heat-stressed cows increased gradually to a maximum of $40.7^{\circ} \mathrm{C}$, which is a level that is maintained by high milk-yielding cows under natural conditions during hot summer months. Control cows maintained normothermia (body temperature of $38.7^{\circ} \mathrm{C}$ ).

\section{Experiment 1: delayed effect of heat stress on medium- sized follicles}

On the day of examination (day 3 of the subsequent cycle) in both control and heat-stressed cows, a mean of one medium-sized follicle per cow was recognized as a follicle from the preceding cycle. These follicles had not been dissected. The number of medium-sized follicles that had emerged during the first follicular wave of the subsequent cycle was similar in control and heat-stressed cows (Table 1). More healthy medium-sized follicles were counted in control cows than in heat-stressed cows (56 and $38 \%$ of total follicles, respectively), but this difference was not significant. Healthy medium-sized follicles in control and heat-stressed cows did not differ in terms of follicular diameter, follicular fluid volume or number and viability of thecal and granulosa cells (Table 1). The concentration of progesterone in the follicular fluid was higher in heatstressed cows than in control cows $(P<0.05$; Table 2). Androstenedione and oestradiol concentrations in follicular fluid did not differ between groups. As expected, the oestradiol:progesterone concentration ratio and the oestradiol:androstenedione concentration ratio in the 
Table 1. Characteristics of healthy medium-sized follicles of control and previously heat-stressed cows at day 20 after heat exposure

\begin{tabular}{lcc}
\hline Characteristic & Control & Heat-stressed \\
\hline $\begin{array}{l}\text { Number of cows } \\
\text { Total number of follicles }\end{array}$ & 6 & 5 \\
$\quad$ per cow & 2.6 & 2.6 \\
$\quad \begin{array}{l}\text { Number of healthy follicles } \\
\text { per cow }\end{array}$ & 1.5 & 1.0 \\
$\quad \begin{array}{l}\text { Diameter (mm) } \\
\text { Follicular fluid volume (ml) }\end{array}$ & $6.7 \pm 0.4$ & $7.7 \pm 0.7$ \\
$\quad$ Number of granulosa cells & $1.5 \pm 0.5$ & $0.4 \pm 0.2$ \\
$\quad \times 10^{6}$ per follicle & & $2.0 \pm 1.0$ \\
$\quad \begin{array}{l}\text { Viability of granulosa cells (\%) } \\
\text { Viability of thecal cells (\%) }\end{array}$ & $54.2 \pm 4.8$ & $60.6 \pm 5.8$ \\
& $>90$ & $>90$ \\
\hline
\end{tabular}

Values are mean or mean $\pm \mathrm{SE}$.

aFollicles that were shown by ultrasonographic monitoring to have grown during the previous (treated) cycle were not dissected; those grown during the first follicular wave of the subsequent cycle were dissected and included in the data set.

bViability of granulosa cells $>50 \%$ and ratio of oestradiol:progesterone $>1$.

follicular fluid of healthy follicles were $>1$ in both groups. Forskolin-stimulated androstenedione production by thecal cells was three times higher in control cows than in heatstressed cows $(P<0.05$; Fig. 1a). Oestradiol production by granulosa cells in the absence or presence of testosterone was also two or three times higher, respectively, in control cows compared with heat-stressed cows $(P<0.05$; Fig. $1 \mathrm{~b})$. The concentrations of progesterone and oestradiol in plasma did not differ between control and heat-stressed cows during heat exposure (days $2-6: 0.6 \pm 0.2$ versus 0.9 $\pm 0.3 \mathrm{ng}$ progesterone $\mathrm{ml}^{-1}$ and $1.3 \pm 0.5$ versus $1.5 \pm 0.3$ pg oestradiol $\mathrm{ml}^{-1}$ in control and heat-stressed cows, respectively), after heat exposure (days $7-19$ of the treated cycle: $1.7 \pm 0.4$ versus $1.5 \pm 0.4 \mathrm{ng}$ progesterone $\mathrm{ml}^{-1}$ and $1.9 \pm 0.6$ and $1.6 \pm 0.4 \mathrm{pg}$ oestradiol $\mathrm{ml}^{-1}$ in control and heat-stressed cows, respectively) and during the subsequent cycle (days 0-3: $0.06 \pm 0.03$ versus $0.08 \pm 0.03 \mathrm{ng}$ progesterone $\mathrm{ml}^{-1}$ and $2.8 \pm 0.9$ versus $2.6 \pm 1.1 \mathrm{pg}$ oestradiol $\mathrm{ml}^{-1}$ in control and heat-stressed cows, respectively).

\section{Experiment 2: delayed effect of heat stress on preovulatory follicles}

The diameter, volume of follicular fluid, total number of granulosa cells and viability of thecal cells of the preovulatory follicles, collected on day 9 of the subsequent cycle, did not differ between control and previously heatstressed cows (Table 3). However, the viability of granulosa cells was lower $(P<0.05)$ in heat-stressed cows than in control cows. The similarly high concentrations of oestradiol (> $550 \mathrm{ng} \mathrm{ml}^{-1}$ ), together with the oestradiol: progesterone and oestradiol:androstenedione concentration
Table 2. Steroid concentrations in the follicular fluid of mediumsized follicles of control and previously heat-stressed cows

\begin{tabular}{lcc}
\hline Steroid & Control & Heat-stressed \\
\hline Oestradiol $\left(\mathrm{ng} \mathrm{ml}^{-1}\right)$ & $23.4 \pm 18.6$ & $76.2 \pm 25.0$ \\
Progesterone $\left(\mathrm{ng} \mathrm{ml}^{-1}\right)$ & $18.0 \pm 8.5$ & $47.8 \pm 11.4^{*}$ \\
Androstenedione $\left(\mathrm{ng} \mathrm{ml}^{-1}\right)$ & $8.6 \pm 1.6$ & $3.9 \pm 2.5$ \\
Oestradiol:progesterone ratio & 1.3 & 1.6 \\
Oestradiol:androstenedione ratio & 2.7 & 19.5 \\
\hline
\end{tabular}

Values are mean \pm SE (control: $n=6$; heat-stressed: $n=5$ ).

*Significantly different from control group $(P<0.05)$.

ratios $>1$ in the follicular fluid (Table 4), indicate that the follicles examined in both groups were oestrogenically active preovulatory follicles. The concentration of androstenedione in the follicular fluid was lower in heatstressed cows than in control cows $(P<0.05)$. LHstimulated androstenedione production was lower in thecal cells obtained from previously heat-stressed cows than in those from control cows (Fig. $2 ; P<0.05$ ). Forskolinstimulated androstenedione production, although decreased, was not affected significantly by heat exposure. Oestradiol production by granulosa cells did not differ between previously heat-stressed and control cows in either the absence or the presence of testosterone (Fig. 2). Basal progesterone production by granulosa cells did not differ between previously heat-stressed and control cows (2.3 \pm 1.2 versus $4.4 \pm 1.1 \mathrm{ng}$ per $10^{5}$ cells, respectively). Basal, forskolin- or LH-stimulated production of progesterone by thecal cells $(0.4 \pm 0.1,2.7 \pm 0.5$ and $3.3 \pm 0.9$ versus $0.3 \pm 0.1,2.5 \pm 0.5$ and $3.7 \pm 0.8$ ng per $10^{5}$ cells, respectively) also did not differ between previously heat-stressed and control cows. The concentrations of progesterone and oestradiol in plasma did not differ between control and heat-stress groups during heat exposure (days 2-6: $1.8 \pm 0.9$ versus $0.7 \pm 0.9 \mathrm{ng}$ progesterone $\mathrm{ml}^{-1}$ and $1.4 \pm 0.2$ versus $1.6 \pm 0.3 \mathrm{pg}$ oestradiol $\mathrm{ml}^{-1}$ in control and heat-stressed cows, respectively), after heat exposure (days 7-19 of the treated cycle: $2.4 \pm 0.7$ versus $3.8 \pm 0.7 \mathrm{ng}$ progesterone $\mathrm{ml}^{-1}$ and $1.4 \pm 0.2$ versus $1.4 \pm 0.2 \mathrm{pg}$ oestradiol $\mathrm{ml}^{-1}$ in control and heat-stressed cows, respectively) and during the subsequent cycle (days $0-7$ : $0.4 \pm 0.2$ versus $0.6 \pm 0.1 \mathrm{ng}$ progesterone $\mathrm{ml}^{-1}$ and $2.6 \pm 0.3$ versus $2.7 \pm 0.4 \mathrm{pg}$ oestradiol $\mathrm{ml}^{-1}$ in control and heat-stressed cows, respectively).

\section{Discussion}

The present study provides, for the first time, evidence for a delayed effect of heat stress on follicular steroidogenesis. The delayed effect was detected in both medium-sized and preovulatory follicles, but was expressed differently in granulosa and thecal cells within each class of follicles.

Two experiments were performed during the winter to avoid any potential seasonal carry-over effects from the 

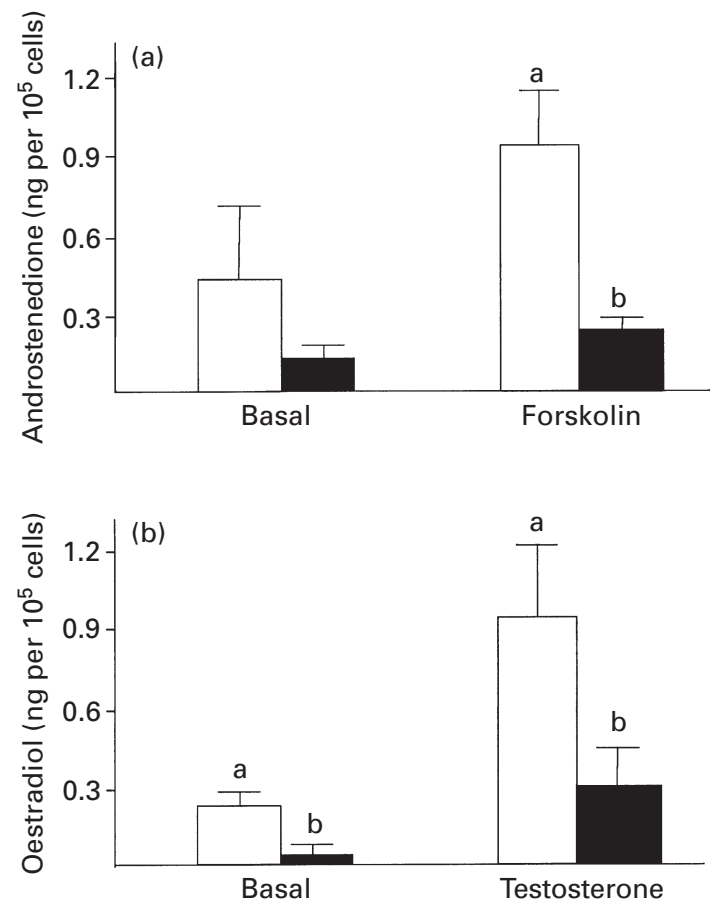

Fig. 1. Delayed effect of heat stress on steroid production in medium-sized follicles. (a) Basal or forskolin-stimulated $\left(10 \mu \mathrm{mol}^{-1}\right)$ androstenedione production by thecal cells and (b) oestradiol production by granulosa cells in the presence or absence of testosterone $\left(300 \mathrm{ng} \mathrm{ml}^{-1}\right)$. Columns represent production of cells obtained from follicles of control $(\square ; n=6)$ or previously heatstressed $(\boldsymbol{\square} ; n=5)$ cows on day 3 of the subsequent cycle, 20 days after heat exposure. Values are mean \pm SE. ${ }^{\text {ab }}$ Different letters indicate significant differences between groups $(P<0.05)$.

previous summer. In addition, the experimental design, in which heat-stressed cows were compared with contemporary control cows, enabled the acute heat exposure to be associated with alterations in follicular function in mediumsized and preovulatory follicles, 20 and 26 days later, respectively. It might be expected that during the processes of development and selection, the healthiest follicle from the cohort of impaired medium-sized follicles would be selected to become the dominant follicle. However, alterations in follicular function were also found in preovulatory follicles from previously heat-stressed cows. Calculations made according to Lussier et al. (1987) showed that the medium-sized or preovulatory follicles studied ( $7.7 \mathrm{~mm}$ or $15.2 \mathrm{~mm}$ in diameter, respectively) had diameters of about $0.5-1.0 \mathrm{~mm}$ when the cows were heatstressed. Follicles in such an early stage of follicular growth are characterized by a high mitotic index of granulosa cells (Lussier et al., 1987) and might be particularly sensitive to environmental changes. It remains to be determined whether very small antral $(<0.5 \mathrm{~mm}$ in diameter) or preantral follicles are also susceptible to heat stress.

In terms of steroid production, the thecal cells were found to be more susceptible than granulosa cells to heat
Table 3. Characteristics of preovulatory follicles of control and previously heat-stressed cows at day 26 after heat exposure

\begin{tabular}{lcc}
\hline Characteristic & Control & Heat-stressed \\
\hline $\begin{array}{l}\text { Number of cows (one follicle } \\
\text { per cow) }\end{array}$ & 5 & 4 \\
Diameter (mm) & $18.2 \pm 1.4$ & $15.2 \pm 1.5$ \\
Follicular fluid volume (ml) & $2.6 \pm 0.4$ & $2.4 \pm 0.5$ \\
$\quad$ Number of granulosa cells & & \\
$\quad \times 10^{6}$ per follicles & $12.3 \pm 2.3$ & $14.6 \pm 1.6$ \\
Viability of granulosa cells (\%) & $42.0 \pm 4.9$ & $25.0 \pm 5.4^{*}$ \\
Viability of thecal cells $(\%)$ & $>90$ & $>90$ \\
\hline
\end{tabular}

Values are mean $\pm \mathrm{SE}$.

*Significantly different from control group $(P<0.05)$.
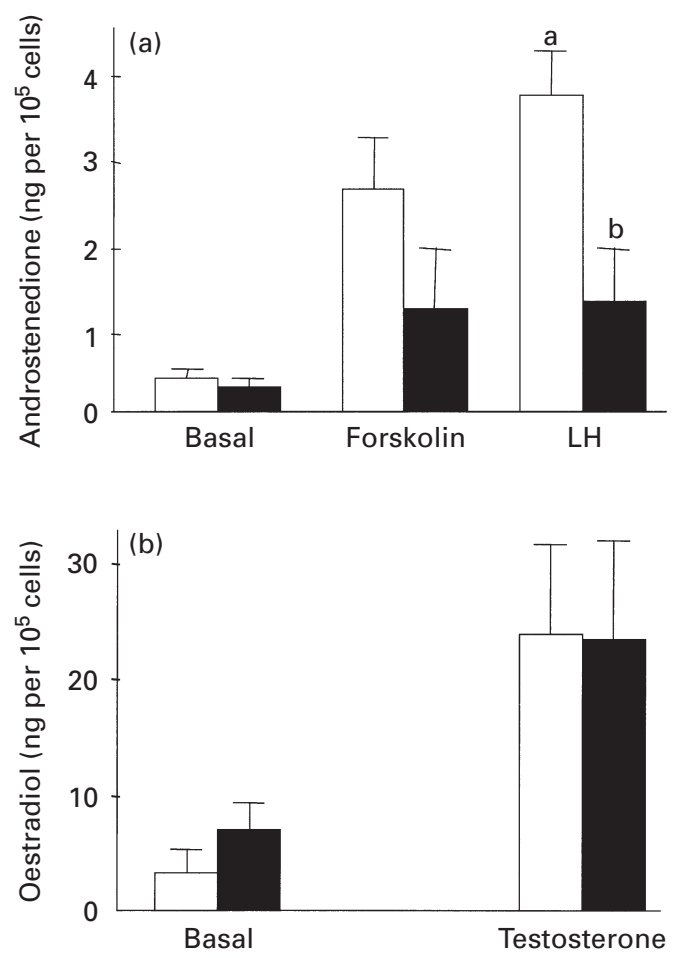

Fig. 2. Delayed effect of heat stress on steroid production in preovulatory follicles. (a) Basal, forskolin-stimulated $\left(10 \mu \mathrm{mol}{ }^{-1}\right)$ or LH-stimulated $\left(50 \mathrm{ng} \mathrm{ml}^{-1}\right)$ androstenedione production by thecal cells, and (b) oestradiol production by granulosa cells in the presence or absence of testosterone $\left(300 \mathrm{ng} \mathrm{ml}^{-1}\right)$. Production of steroids by cells obtained from follicles of control $(\square ; n=5)$ or previously heat-stressed cows $(\mathbf{\square} ; n=4)$ on day 9 of the subsequent cycle $40 \mathrm{~h}$ after $\mathrm{PGF}_{2 \alpha}$ administration, 26 days after heat exposure. Values are mean $\pm \mathrm{SE}$. ${ }^{\mathrm{b} b}$ Different letters indicate significant differences between groups $(P<0.05)$.

stress, and expressed a delayed effect of heat stress in both classes of follicle. The consistent decrease in androstenedione production in both medium-sized and preovulatory follicles in previously heat-stressed cows correlated with the decreased concentrations of androstenedione in their follicular fluid. This delayed effect of heat stress on 
Table 4. Steroid concentrations in the follicular fluid of preovulatory follicles of control and previously heat-stressed cows

\begin{tabular}{lcc}
\hline Steroid & Control & Heat-stressed \\
\hline Oestradiol $\left(\mathrm{ng} \mathrm{ml}^{-1}\right)$ & $600 \pm 122$ & $560 \pm 136$ \\
Progesterone $\left(\mathrm{ng} \mathrm{ml}^{-1}\right)$ & $22.3 \pm 4.0$ & $12.9 \pm 3.6$ \\
Androstenedione $\left(\mathrm{ng} \mathrm{ml}^{-1}\right)$ & $10.2 \pm 1.6$ & $4.8 \pm 1.4^{*}$ \\
Oestradiol:progesterone ratio & 27.0 & 43.0 \\
Oestradiol:androstenedione ratio & 58.8 & 116.7 \\
\hline
\end{tabular}

Values are mean \pm SE (control: $n=5$; heat-stressed: $n=4$ ).

*Significantly different from control group $(P<0.05)$

androstenedione production by thecal cells indicates strongly that the marked decrease in androstenedione production by dominant follicles observed in the autumn (Wolfenson et al., 1997) was due to previous exposure of cows to summer heat stress. It has been shown that early atresia of bovine follicles is characterized by a decrease in androgen production by thecal cells (McNatty et al., 1984). Thus, the above findings may indicate that both classes of follicle obtained from previously heat-stressed cows had been in an early stage of atresia. Early atresia in mediumsized follicles could also be associated with low oestradiol production by granulosa cells and increased progesterone concentrations in the follicular fluid of heat-stressed cows. Unlike the effect on thecal cells, the decreased production of oestradiol by granulosa cells that was noted in mediumsized follicles after heat stress was not carried over to the preovulatory stage. Nevertheless, the delayed effect of heat stress on granulosa cells in preovulatory follicles was expressed in terms of a significant decrease of cell viability. The reason for the difference in the responses of the two cell types to heat stress within each of the two follicular stages, or between the two stages, is not clear. It could be related to the fact that granulosa cells acquire the steroidogenic capacity at a later stage during follicular growth than do thecal cells (Bao and Garverick, 1998).

The mechanism by which heat stress induces a decrease in androstenedione production in thecal cells is not clear. Recent analyses of mRNA content for $\mathrm{LH}$ receptor in thecal cells obtained from preovulatory follicles did not provide any evidence for alterations of mRNA content related to previous heat exposure (Roth et al., 2000b). However, the significant decrease of LH-stimulated, but not of forskolinstimulated, androstenedione production by thecal cells noted in the present study may indicate that heat exposure induced impairment of $\mathrm{LH}$ receptor function. Nevertheless, lack of steroid precursor or compromise of other cell function should be considered. Although a possible delayed effect of heat exposure on $\mathrm{LH}$ secretion was not examined in the present study, its involvement in the attenuated androgen production cannot be ruled out. Seasonal studies that might have shed some light on this subject provided conflicting results regarding plasma $\mathrm{LH}$ concentrations after summer heat stress (Crister et al., 1983; Day et al., 1986; Badinga et al., 1994). Moreover, the specificity of heatstress as the environmental factor responsible for the seasonal variations in $\mathrm{LH}$ secretion has not been examined.

In the present study, the oestradiol content of the follicular fluid of preovulatory follicles was not affected by a previous exposure to acute heat stress. This finding is in agreement with the findings of Ambrose et al. (1999). Comparison of the present findings concerning steroid concentrations in the follicular fluid with those of previous seasonal studies (Badinga et al., 1993; Wolfenson et al., 1997 ) indicates that a decrease in oestradiol concentration may depend on the duration and severity of the thermal stress to which cows are exposed. Decrease of oestradiol concentration in the follicular fluid is more likely to occur after exposure to long-term, chronic (summer) heat stress than to acute heat stress as in the present study. This response would be consistent with the finding that after chronic summer heat stress an eight times decrease in androgen production by thecal cells in the autumn was accompanied by a significant decrease in oestradiol concentration in the follicular fluid (Wolfenson et al., 1997). However, a 5 day acute heat stress (present study) induced a three times decrease in androgen production, which was probably not enough to elicit a decrease in oestradiol concentration in the follicular fluid. In addition, the oestradiol content in the follicular fluid reflects the balance between production of the hormone by the cells and its clearance from the follicle to the circulation. Thus, the discrepancy between steroid production and hormonal follicular fluid content found in the present study could be related to heat-stress-induced alteration in vascular responses. Hyperthermia has been shown to decrease ovarian blood flow (Lublin and Wolfenson, 1996) and to inhibit angiogenesis (Fajardo et al., 1988). Blood flow and vascular density determine the follicular perfusion rate, which directly influences the rates of nutrient uptake and hormonal release by the follicle. The relationships among heat stress, vascularity and steroidogenic capacity require further investigation.

In conclusion, exposure of cows to heat stress resulted in impaired steroidogenesis 20 and 26 days later, in mediumsized and preovulatory follicles, respectively. The delayed effect was expressed in a different way in granulosa and thecal cells within each class of follicles. Granulosa cells expressed low oestradiol production in medium-sized follicles and low viability in the preovulatory follicles. In terms of steroid production, thecal cells appeared to be consistently susceptible to heat stress and expressed a carryover effect on androgen production in both types of follicle. Delayed effects of heat stress on follicular steroidogenic capacity, together with its delayed effects on follicular dynamics (Roth et al., 2000a), as well as on oocyte quality and embryo development (Roth et al., 1999), could be responsible for the low fertility of dairy cows during the autumn. 
The authors would like to thank Y. Graber for technical assistance and the USDA for provision of bLH. This work was supported by a grant from the US-Israel Binational Agricultural Research and Development Fund (BARD).

\section{References}

Ambrose JD, Guzeloglu A, Thatcher MJ, Kassa T, Dias T and Thatcher WW (1999) Long-term follicular dynamics and biochemical characteristics of dominant follicles in dairy cows subjected to heat-stress Journal of Reproduction and Fertility Supplement 54 503-504

Badinga L, Driancourt MA, Savio JD, Wolfenson D, Drost M, De La Sota RL and Thatcher WW (1992) Endocrine and ovarian response associated with the first wave dominant follicle in cattle Biology of Reproduction 47 871-883

Badinga L, Thatcher WW, Diaz T, Drost M and Wolfenson D (1993) Effect of environmental heat stress on follicular development and steroidogenesis in lactating Holstein cows Theriogenology 39 797-810

Badinga L, Thatcher WW, Wilcox CJ, Morris G, Entwistle K and Wolfenson D (1994) Effect of season on follicular dynamics and plasma concentrations of oestradiol-17 $\beta$, progesterone and luteinizing hormone in lactating Holstein cows Theriogenology 42 1263-1274

Bao B and Garverick HA (1998) Expression of steroidogenic enzyme and gonadotropin receptor genes in bovine follicles during ovarian follicular wave: a review Journal of Animal Science 76 1903-1921

Crister JK, Miller KF, Gunsett FC and Ginther OJ (1983) Seasonal LH profile in ovariectomized cattle Theriogenology 19 181-191

Day ML, Imakawa K, Pennel PL, Zalesky DD, Clutter AC, Kittok RJ and Kinder JE (1986) Influence of season and estradiol on secretion of luteinizing hormone in ovariectomized cows Biology of Reproduction 35 549-553

Fajardo LF, Prionas SD, Kowalski J and Kwan HH (1988) Hyperthermia inhibits angiogenesis Radiation Research 114 297-306

Fortune JE, Sirois J, Turzillo AM and Lavoir M (1991) Follicle selection in domestic ruminants Journal of Reproduction and Fertility Supplement 43 187-198

Ginther OJ, Kastelic JP and Knopf L (1989) Intraovarian relationships among dominant and subordinate follicles and the corpus luteum in heifers Theriogenology 32 787-795

Hansen PJ (1997) Effects of environment on bovine reproduction. In Current Therapy in Large Animal Theriogenology pp 403-415 Ed. RS Youngquist. WB Saunders, Philadelphia

Ireland JJ and Roche JF (1983) Development of nonovulatory antral follicles in heifers; changes in steroids in follicular fluid and receptors for gonadotropins Endocrinology 112 150-156

Lublin A and Wolfenson D (1996) Effect on blood flow to mammary and reproductive systems in heat-stressed rabbits Comparative Biochemistry and Physiology 115A 277-285

Lussier JG, Matton P and Dufour JJ (1987) Growth rates of follicles in the ovary of the cow Journal of Reproduction and Fertility 81 301-307
McNatty KP, Heath DA, Henderson KM, Lun S, Hurst PR, Ellis LM, Montgomery GW, Morrison L and Thurly DC (1984) Some aspects of thecal and granulosa cell function during follicular development in the bovine ovary Journal of Reproduction and Fertility 72 39-53

Meidan R, Girsh E, Blum O and Aberdam E (1990) In vitro differentiation of bovine theca and granulosa cells into small and large luteal-like cells: morphological and functional characteristics Biology of Reproduction 43 913-921

Roth Z, Arav A, Bor A, Zeron Y, Ocheretny A and Wolfenson D (1999) Enhanced removal of impaired follicles improves the quality of oocytes collected in the autumn from summer heat-stressed cows Journal of Reproduction and Fertility Abstract Series $\mathbf{2 3} 78$ (Abstract)

Roth Z, Meidan R, Braw-Tal R and Wolfenson D (2000a) Immediate and delayed effects of heat stress on follicular development and its association with plasma FSH and inhibin concentration in cows Journal of Reproduction and Fertility 120 83-90

Roth Z, Meidan R, Preger E, Levi N, Braw-Tal R, Wolfenson D (2000b) Delayed effects of heat stress on steroidogenesis in bovine preovulatory follicles Proceeding of the $14^{\text {th }}$ International Congress on Animal Reproduction, Stockholm 1:15 (Abstract)

SAS Inc (1987) SAS User's Guide $6^{\text {th }}$ Edition. SAS Institute Inc, Cary, NC

Shaham-Albalancy A, Nyska M, Kaim M, Rosenberg M, Fulman $Y$ and Wolfenson D (1997) Delayed effect of progesterone on endometrial morphology in dairy cows Animal Reproduction Science 48 159-174

Shaham-Albalancy A, Rosenberg M, Folman Y, Graber Y, Meidan R and Wolfenson D (2000) Two methods of inducing low plasma progesterone concentrations have different effects on dominant follicles in cows Journal of Dairy Science 83 2771-2778

Shores EM, Picton HM and Hunter MG (2000) Differential regulation of pig theca cell steroidogenesis by $\mathrm{LH}$, insulin-like growth factor I and granulosa cells in serum-free culture Journal of Reproduction and Fertility 118 211-219

Wolfenson D, Thatcher WW, Badinga L, Savio JD, Meidan R, Lew BJ, Braw-Tal R and Berman A (1995) Effect of heat stress on follicular development during the estrus cycle in lactating dairy cattle Biology of Reproduction 52 1106-1113

Wolfenson D, Lew BJ, Thatcher WW, Graber Y and Meidan R (1997) Seasonal and acute heat stress effects on steroid production by dominant follicles in cows Animal Reproduction Science 47 9-17

Wolfenson D, Sonego H, Shaham-Albalancy A, Shpirer $Y$ and Meidan R (1999) Comparison of the steroidogenic capacity of bovine follicular and luteal cells, and corpora lutea originating from dominant follicles of the first or second follicular wave Journal of Reproduction and Fertility $117241-247$

Received 27 October 2000.

First decision 21 December 2000.

Accepted 30 January 2000. 